Archaeology of consumption in Ottoman urban centers: the case study of Iznik Ware from the Belgrade Fortress in the 16th and 17th centuries

By JELENA ŽIVKOVIĆ, UCL Qatar

With VESNA BIKIĆ, Institute of Archaeology in Belgrade and

MYRTO GEORGAKOPOULOU, UCL Qatar

Abbreviated title: Iznik Ware from the Belgrade Fortress in the 16th and 17th centuries

Word count: 4654 (without notes and bibliography)

Date submitted: 10/12/2015

Corresponding author: Jelena Živković, UCL Qatar, Georgetown Building 2nd Floor, Hamad bin Khalifa University, Doha, Qatar.

Email: j.zivkovic.12@ucl.ac.uk 


\title{
Archaeology of consumption in Ottoman urban centers: the case study of Iznik Ware from the Belgrade Fortress in the 16th and 17th centuries
}

\author{
By JELENA ŽIVKOVIĆ
}

\section{With VESNA BIKIĆ and MYRTO GEORGAKOPOULOU}

SUMMARY: This article advocates a holistic approach to consumption studies in the urban centers of the Middle Danube region during the Ottoman period (16-17th century) using the example of Iznik Ware from the Belgrade Fortress. Combined results of archaeological and scientific research provide insight into regional consumption patterns, which is important for the understanding of cultural variability across the Ottoman Empire. This work emphasizes the importance of contextualized studies of archaeological ceramics in the development of postmedieval archaeology.

\section{INTRODUCTION}

The study of consumption in the Ottoman Empire was given priority in the discipline of Ottoman archaeology, and has received considerable attention in previous publications. ${ }^{1}$ Although there have not been many archaeological excavations that attempted to identify consumption patterns in the urban centres of the Ottoman Empire, those undertaken proved to be vital in demonstrating the need for further research on this subject. ${ }^{2}$ This is especially true for the region of the Central Balkans and Middle Danube that are usually omitted from overviews on Ottoman archaeology. ${ }^{3}$ The large archaeological potential of this region lies particularly in the urban centres that testify to a long continuity of occupation between the medieval and post-medieval periods (Fig. 1).

In an introduction to the study of consumption in the Ottoman Empire, Quataert states the importance of two questions relevant to this paper: understanding of consumption patterns in 
relation to production on both imperial and regional levels as well as the relevance of

comparisons between Istanbul and other administrative, trading or manufacturing centres. ${ }^{4}$ Since Belgrade served as one of the administrative centres of the Middle Danube region, understanding of consumption patterns in the town, in relation to production, can illustrate diversity in consumption practices across the Ottoman Empire. In this paper, Iznik Ware consumed during the 16th and the 17th centuries by Belgrade dwellers will be used to explore this relationship further.

\section{IZNIK WARE IN SCHOLARSHIP}

The name of Iznik certainly has a prominent place in the history of ceramics. It is related to one of the most famous ceramic groups of the Islamic world and is certainly the most studied of Ottoman ceramics to date. Various objects attributed to this group were predominantly produced in the Ottoman town Iznik, between the last quarter of the 15 th and the end of the 17 th century, which coincides with the classical period of Ottoman art and architecture. ${ }^{5}$ Most of our knowledge about Iznik ceramics comes from research in the discipline of Art History, and has been based on museum collections, standing architectural monuments or written documents of the Ottoman era. After a modest beginning, during the 16th century several decorative styles were included in Iznik production, each of them introducing different artistic styles that are chronologically sensitive and recognizable among other ceramic classes. This extraordinary potential of Iznik styles was recognized early in archaeology and served as a powerful dating tool. ${ }^{6}$

Besides recognizable styles, Iznik pottery is characterised by a distinctive stonepaste technology that presents an innovative phase in ceramic production of the Islamic World. ${ }^{7}$ This production technology has formed the research subject of several studies which provided 
essential understanding of raw materials and manufacturing processes. ${ }^{8}$ Based on this work, it is commonly accepted that Iznik pottery involves a standardized paste recipe, composed of a white silica body bonded with soda-lead frit and a small amount of clay, coated with a slip of a similar composition but finer texture and transparent alkaline-lead glaze that protects the unique underglaze decoration.

The less known aspect of Iznik pottery relates to its meaning in archaeological contexts of the Early Modern Period. In other words, what kind of socially meaningful information can we draw from archaeologically documented Iznik Ware in different parts of the Ottoman Empire? Although many archaeological publications give special attention to Iznik pottery, they centre on different aspects. ${ }^{9}$ In the northern border region of the Ottoman Empire research on Iznik pottery is still at an early phase, not only with regards to systematic records of finds but also their comprehensive analysis. Nevertheless, one should mention a number of recently published articles, primarily by researchers in Hungary, who discuss various aspects of Iznik ceramics, such as typology, chronology and distribution. ${ }^{10}$ Overall one can conclude that despite important developments in research on Iznik ceramics, the question of consumption is not problematized enough, and usually the same evaluation methods, and therefore a similar meaning, is ascribed to pottery shards excavated in Istanbul and the Ottoman provinces.

This paper primarily aims to contribute to a better understanding of Iznik pottery and technology in the archaeological context of Ottoman towns in the Middle Danube region. The technological characterisation of twelve Iznik tablewares, representative of the 16th-17th-century deposits at the Belgrade Fortress, presents a preliminary attempt at understanding the materiality of this Ware in the regional context of Balkan towns. At the same time, the results of scientific examination support previously published conclusions, reinforcing them with new data. ${ }^{11}$ This 
article, however, does not aim to participate in the discussion on the origins of this technology or the raw materials used in production. Instead, it offers a different framework for consideration of Iznik pottery and technology in Ottoman Rumelia.

\section{HISTORICAL BACKGROUND}

At the beginning of the Modern Age the development of Belgrade was marked by a balance of power between the two empires, the Ottoman and the Austrian. After the Ottoman conquest in 1521 a new chapter for Belgrade was opened. ${ }^{12}$ From a primary military function and the main strategic frontier fortress position it became an intermediary centre for distribution of supplies to the Ottoman armies campaigning in central Europe, steadily increasing its economic strength. ${ }^{13}$ In accordance with this new role in the following decades, until the end of the century, instead of fortifications, large armaments arms and food storehouses were built. ${ }^{14}$ The short-lived Austrian occupation (1688-1690) did not bring significant changes in this regard. After the Ottoman re-conquest in 1690 and onwards, throughout the 18th and 19th centuries, Belgrade maintained its military function as a key frontier stronghold. Therefore both empires, the Austrian and the Ottoman, did their best to fortify the town to become the strongest fortress of south-eastern Europe. The large building activities of the time - based on the most advanced Vauban's fortification design — were followed by extensive demolition of previous fortifications, as well as significant terrain levelling, especially within the fortress on the top hill, the Upper Town area. Under the Ottoman rule (1690-1717 and 1739-1791) Belgrade retained its key strategic importance to sustain the Empire's European possessions. ${ }^{15}$

During the Ottoman government the entire space of the Upper town had a strictly military function, and inhabitants were soldiers with supporting personnel. Beside military buildings (barracks, storehouses, and arsenal) mosques, hammams and caravanserais were built within the 
city walls. However, in the vicinity of the Great Mosque in the Lower town (Donji grad) previously the church of the Ascension of the Virgin Mary of the palace of the Belgrade Metropolitan residence — the Muslim civic settlement, the so-called Great (Imperial) Mahalle, was raised shortly after establishing the Ottoman government. ${ }^{16}$ In this prominent place, influential and wealthy inhabitants organized their affairs and households. In addition, in surrounding suburbs mahalleler were raised, containing households of merchants and artisans, thus creating a dynamic environment for international trade. ${ }^{17}$

The peace of Svistova in 1791 marked the last military conflict between the Austrian and Ottoman empires over the town. Belgrade remained the Ottoman frontier fortress, but its role was not strictly military. It became an administrative centre of the Ottoman authorities while they struggled against the rebellious Serbs and after acquiring independence in 1867, the Serbian troops used the Belgrade Fortress as an enclosed complex of barracks and storehouses. ${ }^{18}$

\section{IZNIK WARE IN THE ARCHAEOLOGICAL CONTEXT OF THE BELGRADE FORTRESS}

Following the Ottoman conquest in 1521, the social structure of the Belgrade Fortress was altered in favour of the Muslim population, which resulted in changes in the pottery assemblages. Archaeological contexts dating to the Ottoman period - from the 16th to the 19th centuries - are very rich in pottery, testifying to intensive activities within the defensive walls. In addition, the distribution of pottery indicates extensive use of space, which fits with wide range of building activities and speaks in favour of an intensive settlement process. Pottery for everyday use is by far the most prevalent, including both cooking and table vessels. Only a few luxurious pottery classes were recorded, Iznik and both Chinese subclasses, white porcelain and celadon. Among them, Iznik Ware was present in the largest amount, yet it was less than $1 \%$. Importantly, the quantity of Iznik Ware is consistent throughout the Ottoman period in Belgrade. 
The results of stratigraphic analyses indicate that Iznik wares occurred during the 16th17th centuries, more precisely in two main chronological phases of the Ottoman building activities. ${ }^{19}$ The time span of the first phase is relatively short and could be placed between the Ottoman conquests of the town in 1521 and the end of the century. The second phase encompasses mostly the 17 th century period, and ended with the Austrian conquest in 1717 . The most accurate chronology of Iznik pottery could be established only in the case of specimens in the complex of the Great Mosque in the Lower Town, given the clear stratigraphy of the Ottoman settling levels. ${ }^{20}$ For most other finds of Iznik, dating is established by comparing records of building activities and the accompanying finds in corresponding layers, mainly coins and assemblages of ceramic vessels.

Although clearly expressed in architecture, archaeological contexts of the first Ottoman phase are quite poorly illustrated by ceramic finds. Fortunately, some of them are very informative. One of the most valuable, with the earliest finds of Iznik bowls, was uncovered in the complex around the Imperial Mosque. ${ }^{21}$ Just after the Ottoman conquest in the ruins of the old palace two temporary constructions - huts or cottages — were built; one of them had access to the cellar of the old (medieval) building. Beside a set of five Iznik vessels that were uncovered in one of the huts (samples BGIZ 10, BGIZ 12 and BGIZ 13), fragments of some other vessels were found in waste pits nearby (sample BGIZ 9) and above the cellar floor (sample BGIZ 11), along with an assemblage of everyday table and cooking pottery. ${ }^{22}$ Of the same date, and with a very similar accompanying assemblage of bowl, pot and jug types (types Nos. I/1, II/2, II/7, II/16, III/2, III/29) ${ }^{23}$, a shard of Iznik ware (sample BGIZ 8) was uncovered at the Upper Town, in a waste pit that was dug next to the south-eastern wall, where the Clock gate was built sometime later. 
In the second chronological phase — that roughly encompasses the 17 th century — the finds of Iznik came mostly from waste pits, as well as from levelling layers formed during the construction works in the first decades of the 18th century. Specifically, the ground level of the Upper Town was lowered between one and three meters at the eastern part and filled up at the western part at the same time to form a plateau; all the excess earth was thrown down the slopes in the Lower Town and Western Outer City. ${ }^{24}$ With these works almost all previous layers and various objects, including those from the Ottoman period, were either destroyed — in the central part of the Upper Town — or dislocated. However, several waste areas that remained in situ after the Austrian construction works proved to be highly indicative with respect to the chronology of pottery, and thereby the interpretation of Iznik. These are the contexts from the Western and Eastern fortified suburbs (BGIZ 1-4), as well as the western part of the Upper Town (BGIZ 5-7). A number of indicative ceramic vessels, such as glazed footed bowls, spouted jugs and globular cooking pots (Types Nos. I/1, I/2, I/5, I/13, I/14, III/2, III/3, II/4, II/5, II/7, II/18, II/23), ${ }^{25}$ allows to establish a more precise chronology of these contexts, placing them in the first half of the 17th century.

\section{STYLISTIC AND FUNCTIONAL CHARACTERIZATION OF IZNIK POTTERY FROM THE BELGRADE FORTRESS}

For the purposes of this study twelve sherds from the above described archaeological contexts were selected for stylistic and chemical analyses. Ceramic samples are decorated in different styles, which roughly sets a chronological framework for their production dates. ${ }^{26}$ In some cases the dating was seriously limited due to the usual fragmentation of archaeological pottery. Where it was not possible to date potsherds by style, archaeological context was used as a terminus ante quem. 
Stylistic characterization parallels were found in several relevant publications about Iznik pottery. ${ }^{27}$ It is possible, with a higher degree of certainty, to identify the 'Golden Horn' or 'Spiral' style dated between 1535-1545 (BGIZ 2) (Fig. 3), 'Damascus' style dated to the third quarter of the 16th century (BGIZ 1, BGIZ 4 and BGIZ 10) (Figs 2, 4 and 10) and 'Rhodian' style with the Armenian bole red dated to 1575-1580 (BGIZ 6) (Fig. 6). The fragment of the blue-and-white bowl (BGIZ 12) (Fig. 12) can probably be dated to the second quarter of the 16th century, which can also be confirmed by the archaeological context. Other potsherds have only blue-and-white (BGIZ 8, BGIZ 9, BGIZ 11 and BGIZ 13) (Figs 8, 9, 11 and 13) or blue and turquoise details (BGIZ 5) (Fig. 5), which is insufficient for a complete reconstruction but at least two samples (BGIZ 9 and BGIZ 11) (Figs 9 and 11) can be dated to the $c$. middle of the 16th century based on the archaeological context. Finally, the fragment with blurred green colour (BGIZ 7) (Fig.7) was probably produced at the end of the 16th or the first half of the 17th century.

All fragments of Iznik ceramics from Belgrade can be classified as parts of eating and serving vessels. The absence of other types of Iznik ceramics, such as tiles or decorative ornaments, suggests an interesting consumption pattern, limited to domestic use. Apart from one lid (Fig.3), the analysed assemblage contains dishes and bowls used as tableware in the new households of the Ottoman Belgrade. It is hard to suggest what kind of meals were served in these vessels, but insight into Ottoman archives suggests dishes such as 'sweetmeat', puddings or lamb chops. ${ }^{28}$ Certainly, the regional varieties of dishes made of grains, fruits, vegetables, meats, and sweets should be taken into consideration. ${ }^{29}$ 
The aim of the chemical analyses was to understand the composition of Iznik pottery excavated in the provincial urban context of the Empire and compare it with previously published results from the main production centres and Istanbul. ${ }^{30}$

For the bulk chemical analyses of samples from Belgrade a scanning electron microscope (SEM: JEOL JSM 6610LV) with an attached energy dispersive spectrometer (EDS: Oxford Instruments $\mathrm{X}-\max ^{\mathrm{N}} 50$ operated with the Aztec software) was used. Analyses were run in high vacuum conditions, at an accelerated voltage of $20 \mathrm{kV}$, working distance $10 \mathrm{~mm}$, process time 5 , acquisition time set to 60 s Livetime. In order to monitor the beam energy, a cobalt standard was measured periodically, setting the deadtime to $40 \%$ by adjusting slightly the spot size. Sections were cut to include the body, slip, and glaze, with different colourants included on the latter, where relevant. These were mounted in resin and polished to $0.25 \mu \mathrm{m}$. For quantitative bulk analyses average values for 3-5 bulk area scans of the body, slip and glaze were calculated. Analysed bulk areas of glazes were selected to present clean zones with occasional tin particles spread through the glazes. The analytical areas were standardized at approximately $100 \times 120 \mu \mathrm{m}$ using x800 magnification for glazes, while slips and bodies were analysed with areas of $1000 \times 1000 \mu \mathrm{m}$ in size at $\times 100$ magnification. The performance of the instrument was monitored using the Corning Glass Standard C, a high lead glass similar to the soda-lead glaze characteristic of Iznik. ${ }^{31}$ Precision, estimated as relative standard deviation, was found to be within 3\% for major elements and deteriorates as concentration approaches the detection limits of the EDS at around $0.1 \%$. The relative difference of the mean to the certified value is within $5 \%$ for most elements, with the exception of barium and lead where it is within $10 \%$ and cobalt whose composition approached the detection limits of the instrument and the difference is $13 \%$. 
The results of SEM-EDS analyses of Iznik pottery excavated at the Belgrade Fortress reinforce previously published conclusions about the production technology and composition of Iznik wares and the production debris excavated at Kütahya, Iznik and Istanbul. ${ }^{32}$

Iznik vessels are composed of a stonepaste body, made from well-ground silica crystals bonded with a network of interstitial glass and small proportions of clay. Quartz particles range in size between $25-150 \mu \mathrm{m}$, bonded together with both lead and alkaline frit types. The bulk chemical composition shows, besides dominant silica, around 1-3\% of sodium, lead, calcium and aluminium oxides, together with $c .1 \%$ of potassium, iron and magnesium oxides (Table 1). The results show that there is no significant difference in the paste recipe between pots produced in the first half and the end of the 16th century.

The bodies of Iznik vessels were coated with white slips, made of the same stonepaste type, with some differences in the texture and chemical composition (Table 2). The thickness of the slips ranges between $300-600 \mu \mathrm{m}$ while the thickness of the slip-glaze interaction layer is around $300 \mu \mathrm{m}$. Quartz minerals in the slips are finer than in the bodies $(20-50 \mu \mathrm{m})$. They are bonded with a less-dense network of interstitial glass. Compositionally, this glass in the slips contains less iron and magnesium oxides (less than 1\%), pointing to significant care taken by the potters during preparation. Apart from that, contents of sodium, potassium, aluminium, lead and calcium oxides are comparable with the bodies.

Iznik glazes are of the lead-alkaline type, with the addition of tin oxide that appears both in solution and in the form of particles (Table 3). The content of the lead oxide varies between $30-40 \%$, and it is typically lower in the group of blue-and-white pottery produced during the first half of the 16th century, as already noted by Tite and others before. ${ }^{33}$ The opposite is true for the tin oxide content, which tends to be lower in pottery produced towards the end of the 16th 
century (range between 2-6\%). The same cannot be stated for the soda content that varies between $8-11 \%$ without any visible pattern. In general, calcium, potassium, aluminium, magnesium and iron oxide contents are less than $1 \%$. In the case of several samples with very distinctive blue and green colours, mineral-based pigments are detected in the glaze as copper or cobalt oxides.

\section{DISCUSSION}

The interdisciplinary analysis of Iznik Ware in the context of Ottoman Belgrade opens several interesting topics for discussion. The study of decorative styles in the archaeological contexts of Ottoman Belgrade demonstrates in more than half of the presented samples the evident gap between approximate dates of production and deposition of Iznik pottery (Table 4). This can be methodologically challenging since a difference of several decades represents a significant time span for chronological considerations in post-medieval archaeology. The case study calls for a precaution in dating post-medieval deposits based exclusively on fineware such as Iznik ceramics. Instead, higher importance should be placed on contextualized studies of archaeological deposits for the development of Ottoman archaeology.

Another significant aspect that should be considered is the presence of Iznik pottery in two depositional phases at the Belgrade Fortress. The first group of Iznik vessels (samples BGIZ 8-13), dated to the 16th century, seem to encompass contemporary products, made and utilized during the first period of the Ottoman rule over the town. It almost certainly can be related with when the Muslim newcomers, both civilians and members of the military garrisons, settled in the Fortress. The new consumption phase in the history of Belgrade can also be confirmed by various earthenware - that is a testament to the new taste and standards of the Belgrade population. ${ }^{34}$ The presence of Iznik vessels can be interpreted as either personal belongings 
brought by the new citizens of Belgrade or those imported through newly established trading routes. Most likely a combination of the two was the reason Iznik Ware was present. A greater challenge lies with the second group of vessels (samples BGIZ 1-7), particularly in understanding why a large gap in the chronological timeline between the production and the deposition dates of Iznik Ware exists. Interestingly, the same situation is reported for Ottoman Hungary by Kovács. ${ }^{35}$ In a context in the Royal palace in Buda, Iznik ceramics made during the 16th century were found to be associated with late 17th-century domestic pottery. Similar finds are documented during excavations in Székesfehérvár, and like the former case no specific interpretation was offered. Those contexts could be explained on the basis of the utilitarian nature of waste pits that are sometimes used over a long time, but the evidence deriving from archaeological excavations do not support this conclusion.

On the other hand, Iznik vessels could be seen as particularly valuable objects that were treasured in families for several generations, but then discarded during the 17 th century in waste pits for different reasons. This conclusion would explain both the chronological gap between dates of production and deposition as well as the even quantity of Iznik Ware in different periods. Additionally, maybe one can consider a similar pattern as in the case of porcelain and celadon in particular, where the duration of consumption is not limited by the time of production; the high value of some objects meant that they were guarded for centuries, thus both Juan and Ming celadon were available for purchase in the 18 th century. ${ }^{36}$ This interpretation would suggest that products of Iznik workshops had a much higher social value in the Ottoman provinces than would be expected for the 17 th century, based on what other literature suggests. ${ }^{37}$

The appearance of Iznik tableware in Belgrade should also be considered in terms of the wider economic transformation in the urban centres of the Ottoman Balkans. After the final 
conquest of Hungary in 1541, intensive trading networks were developed in the Middle Danube region. Soon after the military campaign, merchants from the city-state of Dubrovnik settled in Belgrade, creating their own colony and enjoying trading rights under the Ottoman sultans. ${ }^{38}$ Among other merchants, they became an important link between different parts of the Empire as well as for international trade with Austria and Italy. ${ }^{39}$ The appearance of Iznik pottery in Serbian Orthodox monasteries from the second half of the 16th century onwards is also interpreted as the result of their trading activities. ${ }^{40}$ Parallel to the construction of new distribution networks in the Ottoman Balkans, Iznik pottery lost its original purpose as an elite product due to the lack of support from the royal court at the end of the 16th century, and this resulted in increased production for market trade. ${ }^{41}$ It stayed, however, unclear what Iznik Ware meant to the new, non-elite, consumers and how they used them to negotiate their positions in Ottoman society. In this discussion, it is important to emphasize that the quantity and distribution of Iznik Ware stayed unchanged in the Belgrade Fortress. That means, even if products of Iznik suddenly became more available through the new trading networks and cheaper in markets, this did not have broader consequences in provinces, at least in the case of Belgrade. However, Belgrade is not the only site where the absence of 17 th-century Iznik products is evident. According to the published material, similar cases were documented at several sites in Hungary, ${ }^{42}$ Osijek in Croatia ${ }^{43}$ and even for Dubrovnik at the Adriatic coast. ${ }^{44}$ The correlation in trends of consumption between Belgrade and southern Hungarian towns indicate the existence of a regional network, created between people that enjoyed similar social status in urban centres. The same regional pattern is repeated in the 18th-century during the Austrian domination, visible in consumption of Haban pottery in Hungarian towns and Belgrade. ${ }^{45}$ In that sense, the absence of substantial quantities of Chinese porcelain in the $17^{\text {th }}$-century Belgrade presents an interesting 
exception from the regional pattern, considering its occurrence in Ottoman towns in Hungary as well as in Istanbul where Chinese Ware replaced Iznik Ware as a new symbol of the elites. ${ }^{46}$

Finally, technology holds a significant place in the examination of material culture within a local context. In the particular case of Ottoman Belgrade, the results of SEM-EDS analysis confirm the standardized character of Iznik pottery, as was suggested in previous works. ${ }^{47}$ Even small differences, useful for chronological differentiation — such as slight variations in the content of tin and lead oxides — are clearly visible in the Belgrade material. The results also reinforce production and distribution perspectives of Iznik Ware in the Balkan Peninsula, excluding the possibility of regional imitations. In the context of consumption, the production technology marks an even sharper difference between Iznik fritware and various types of earthenware that dominate the 16th-17th-century assemblage. Technology gives insight into the complexity of the production process, implicating high costs of both human engagement and raw materials, all of which are confirmed in written documents. ${ }^{48}$ In the local context of Ottoman Belgrade, technology emphasizes previous conclusions, highlighting the truly luxurious status of Iznik Ware in the urban centres of the Middle Danube region.

\section{CONCLUSION}

This analysis of Iznik ceramics documented in various archaeological contexts of the Belgrade Fortress demonstrates its effectiveness for establishing consumption patterns in Ottoman provinces during the 16 th and 17 th centuries. This article advocates a context-based approach in interpreting archaeological remains from the Middle Danube region, an area that is important for the understanding of cultural variability in the Ottoman Empire. This study also argues that even in the case of well-known ceramics such as Iznik Ware, regional consumption patterns do not necessarily correlate with models established elsewhere. For example, the 
market-open orientation of Iznik workshops in the 17th century towards broader social classes, resulting from a lack of support from the royal court as well as an association of Ottoman elites with Chinese porcelain, ${ }^{49}$ cannot be confirmed at sites in the middle Danube region. However, residents of the 17th-century Belgrade used Iznik pots produced in several different phases of the 16th century. Since the scientific examination indicates that local imitations can be almost certainly excluded, this pattern opens a discussion about the social meanings and the distribution networks of this Ware in the Ottoman provinces.

\section{ACKNOWLEDGMENTS}

We would like to express our gratitude to Mrs Shrouk Abdelgafar for proof-reading this text.

\section{BIBLIOGRAPHY}

Atasoy, N. 1989, 'The types and forms of Iznik pottery', in Atasoy \& Raby 1989, 37-47.

Atasoy, N. \& Raby, J. 1989, Iznik the Pottery of Ottoman Turkey, London: Alexandria Press.

Ayers J. 1984, Chinese porcelain of the sultans in Istanbul, Transactions of the Oriental ceramic society 47: 77-104.

Bajalović - Hadži-Pešić, M. 1984, 'Nalazi Turske keramike iz Iznika u Srbiji', in Han 1984, 311 329.

Balla, M. 2005, 'Beyond style. A provenance study of Iznik pottery by means of NAA', in Gerelyes 2005, 63-68.

Baram, U. \& Carroll, L. (eds) 2002, A Historical Archaeology of the Ottoman Empire. New York: Cluwer Academic Publishers. 
Bikić, V. 2003, Gradska keramika Beograda 16-17 vek, Belgrade: Archaeological Institute.

Bikić, V. 2006, 'Venetian influences in the eastern Adriatic hinterland', in: Guštin, Gelichi \& Spindler 2006, 201-210.

Bikić, V. 2007, 'The early Turkish stratum on the Belgrade Fortress', BYZAS 7, 515-522.

Bikić, V. 2012, 'The Haban pottery from the Belgrade Fortress: Archaeological Contexts, Chronology, Decorative Designs', Starinar LXII, 205-227.

Brill, R.H. 1999, Chemical Analyses of Early Glasses Volume 2, New York: Corning Museum of Glass.

Carroll, L. 1999, 'Could've been a contender: the making and breaking of "China" in the Ottoman Empire', International Journal of Historical Archaeology 3:3, 177-790.

Carroll, L. 2002, 'Chapter 6. Toward an archaeology of non-elite consumption in Late Ottoman Anatolia', in Baram \& Carroll 2010, 161-177.

Carswell, J. 1998, Iznik Pottery, London: The British Museum Press.

Čubrilović, V. 1974, Istorija Beograda 1, Beograd: Srpska akademija nauka i umetnosti.

Evliyâ Çelebi b. Derviş Mehemmed Zillî. 2001, Evliyâ Çelebi Seyahatnâmesi. Topkapı Sarayı Kütüphanesi Bağdat 307 Numaralı Yazmanın Transkripsiyonu - Dizini. 5. Kitap. Eds. Y. Dağl1, S. A. Kahraman, İ. Sezgin. İstanbul: Yapı Kredi Yayınları.

Gerelyes, I. (ed.) 2005, Turkish Flowers Studies on Ottoman Art in Hungary, Budapest: Hungarian National Museum.

Gerelyes, I. 2008, 'Types of Oriental pottery in archaeological finds from the 16th and 17th centuries in Hungary', Acta Orientalia Academiae Scientiarum Hungaricae 61:1/2: 65-76. 
Guštin, M., Gelichi S. \& Spindler, K. (eds.) 2006, The Heritage of the Serenissima - The presentation of the architectural and archaeological remains of the Venetian Republic, Proceedings of the international conference (Izola-Venezia 4-9.11.2005), Koper: Založba Annales Mediterranea.

Guštin, M., Bikić, V. \& Mileusnić, Z. 2008, Ottoman times, the Story of Stari Bar, Montenegro, Ljubljana: Zalozba Annales.

Han, V. (ed.) 1984, Gradska kultura na Balkanu (XV-XIX vek), Beograd: Srpska akademija nauka i umetnosti.

Henderson, J. 1989, 'Iznik ceramics: a technical examination’ in Atasoy \& Raby 1989, 65-71.

Henderson, J. \& Raby, J. 1989, 'The technology of fifteenth century Turkish tiles: an interim statement on the origins of the Iznik industry', World Archaeology 21:1, 115-132.

Holl I. 2005, Fundkomplexe des 15-17. Jahrhunderts aus dem Burgpalast von Buda, Varia Archaeologica Hungarica XVII, Budapest: Instituti Archaeologici Academiae Scientiarum Hungaricae.

Inalcik, H. 1994, An Economic and Social History of the Ottoman Empire, volume I 1300-1600, Cambridge: Cambridge University Press.

Kovács, G. 2005, 'Iznik pottery in Hungarian archaeological research' in Gerelyes 2005, 69-86.

Lane, A. 1957, Later Islamic Pottery: Mesopotamia, Egypt, Persia, London: Faber and Faber.

Milošević, B. \& Topić, N. 2010, 'Dubrovački nalazi keramike iz Iznika', Starohrvatska prosvijeta III:37, 147-170. 
Ostapchuk, V. \& Bilyayeva, S. 2009, 'The Ottoman northern Black Sea frontier at Akkerman fortress: the view from a historical and archaeological project', in Peacock 2009, 137-170.

Paynter, S., Okyar, F., Wolf, S. \& Tite, M.S. 2004, 'The production technology of Iznik potterya reassessment', Archaeometry 46:3, 421-437.

Peacock A.C.S. (ed.) 2009, The Frontiers of the Ottoman World. New York: Oxford University Press.

Petersen, A. 2013, 'Historical archaeology of the Ottoman Empire', in Smith 2013, 5653-5664.

Popović, M. 2006, Beogradska tvrdjava, Beograd: Javno preduzeće 'Beogradska tvrdjava'.

Popović, M. \& Bikić, V. 2004, Kompleks srednjevekovne mitropolije u Beogradu, Istraživanja u Donjem gradu Beogradske tvrđave, Beograd: Arheološki Institut.

Quataert, D. 2000, 'Introduction', in Quataert 2000, 1-15.

Quataert, D. (ed.) 2000, Consumption Studies and the History of the Ottoman Empire 1550-1922. New York: State University of New York Press.

Raby, J. 1989, 'The making of an Iznik pot', in Atasoy \& Raby 1989, 50-66.

Radić, M. 2015, Osijek and Surrounding Area in the Ottoman Period exhibition catalogue, Osijek: Muzej Slavonije.

Šabanović, H. 1964, Turski izvori za istoriju Beograda, knjiga prva, Beograd: Istorijski Arhiv.

Šabanović, H. 1970, 'Urbani razvitak Beograda od 1521. do 1688', Godišnjak grada Beograda XVII, 9-42.

Smith, C. (ed.) 2013, Encyclopedia of Global Archaeology, New York: Springer. 
Tite, M. 1989, 'Iznik pottery: an investigation of the methods of production', Archaeometry 31:2, 115-32.

Tite, M.S., Shortland, A.J., Schibille, N. \& Degryse, P. 2016, 'New data on the soda flux used in the production of Iznik glazes and Byzantine glasses', Archaeometry 58:1, 57-67.

Tričković, R. 1992, ‘Beograd pod turskom vlašću 1521-1804. Godine’, Zbornik za orijentalne studije 1, 93-137.

Veselinović, R. 1984, 'Razvitak zanatlijsko-trgovačkog sloja srpskog društva pod stranom vlašću u XVII i XVIII veku', in Han 1984, 97-139.

Vroom, J. 2007, 'Kütahya between the lines: post-medieval ceramics as historical information', Hesperia Supplements 40, 71-93.

Walker, B. 2009, 'Identifying the Late Islamic period ceramically', In Walker 2009, 37- 65.

Walker, B. (ed.) 2009, Reflections of the Empire: Archaeological and Ethnographic Studies on the Pottery from Ottoman Levant. Annu. Am. Sch. Oriental Res. 64. Boston: American Schools of Oriental Research.

Walker, B. 2013, 'Ottoman archaeology: Localizing the imperial', in Smith 2013, 5642-5653. 


\begin{tabular}{|l|l|c|c|c|c|c|c|c|c|c|c|}
\hline Code & Production date & $\mathrm{SiO}_{2}$ & $\mathrm{PbO}$ & $\mathrm{Na}_{2} \mathrm{O}$ & $\mathrm{CaO}$ & $\mathrm{Al}_{2} \mathrm{O}_{3}$ & $\mathrm{~K}_{2} \mathrm{O}$ & $\mathrm{MgO}$ & $\mathrm{FeO}$ & $\mathrm{TiO}_{2}$ & $\mathrm{CuO}$ \\
\hline BGIZ 1 & c. $1550-1575$ & 91.4 & 1.6 & 1.6 & 1.3 & 1.5 & 0.5 & 0.8 & 0.7 & - & - \\
\hline BGIZ 2 & $c .1535-1545$ & 86.1 & 2.7 & 2.3 & 2.6 & 2.5 & 0.8 & 1.3 & 0.9 & 0.1 & - \\
\hline BGIZ 4 & c. $1550-1575$ & 89.9 & 0.6 & 1.8 & 1.8 & 2.6 & 0.7 & 1.1 & 1.0 & - & - \\
\hline BGIZ 5 & $c .1530-1550 ?$ & 88.9 & 1.2 & 2.4 & 2.0 & 2.0 & 0.7 & 1.0 & 0.9 & - & - \\
\hline BGIZ 6 & $c .1575-1580$ & 87.1 & 1.4 & 3.3 & 2.6 & 2.2 & 0.8 & 1.0 & 1.0 & - & - \\
\hline BGIZ 7 & $c .1600$ & 88.8 & 1.2 & 2.6 & 2.2 & 2.2 & 0.6 & 0.9 & 0.9 & - & - \\
\hline BGIZ 8 & $c .1530-1550 ?$ & 86.8 & 2.6 & 2.1 & 2.4 & 2.5 & 0.8 & 1.0 & 1.0 & - & - \\
\hline BGIZ 9 & $c .1550$ & 86.3 & 1.7 & 2.5 & 2.7 & 2.9 & 0.8 & 1.3 & 1.3 & 0.1 & - \\
\hline BGIZ 10 & c. $1550-1575$ & 89.6 & 2.4 & 1.6 & 1.9 & 1.5 & 0.4 & 0.9 & 0.7 & 0.0 & 0.4 \\
\hline BGIZ 11 & $c .1550$ & 88.1 & 2.0 & 2.6 & 2.0 & 2.4 & 0.8 & 0.9 & 0.9 & 0.0 & - \\
\hline BGIZ 12 & c. $1530-1550$ & 88.2 & 1.7 & 2.3 & 2.8 & 2.2 & 0.6 & 0.9 & 1.2 & 0.3 & - \\
\hline BGIZ 13 & $c .1530-1550$ & 87.0 & 1.9 & 2.8 & 1.9 & 3.0 & 0.8 & 1.1 & 1.0 & 0.1 & - \\
\hline
\end{tabular}

Table 1. SEM-EDS bulk analyses of bodies. All results are normalized to $100 \mathrm{wt} \%$.

\begin{tabular}{|l|l|c|c|c|c|c|c|c|c|c|}
\hline Code & Production date & $\mathrm{SiO}_{2}$ & $\mathrm{PbO}$ & $\mathrm{Na}_{2} \mathrm{O}$ & $\mathrm{CaO}$ & $\mathrm{Al}_{2} \mathrm{O}_{3}$ & $\mathrm{~K}_{2} \mathrm{O}$ & $\mathrm{MgO}$ & $\mathrm{FeO}$ & $\mathrm{CuO}$ \\
\hline BGIZ 1 & c. $1550-1575$ & 93.7 & 1.3 & 1.4 & 0.7 & 1.5 & 0.4 & 0.3 & 0.1 & - \\
\hline BGIZ 2 & c. $1535-1545$ & 90.6 & 1.8 & 2.1 & 1.6 & 1.9 & 0.5 & 0.8 & - & - \\
\hline BGIZ 4 & c. $1550-1575$ & 94.0 & 0.8 & 1.2 & 0.7 & 1.5 & 0.4 & 0.3 & 1.0 & - \\
\hline BGIZ 5 & c. $1530-1550 ?$ & 92.4 & 0.5 & 2.0 & 1.0 & 2.1 & 0.6 & 0.5 & 0.3 & - \\
\hline BGIZ 6 & c. $1575-1580$ & 92.4 & 0.5 & 2.0 & 1.0 & 2.1 & 0.6 & 0.5 & 0.3 & - \\
\hline BGIZ 7 & c. 1600 & 92.6 & 0.8 & 1.8 & 1.7 & 1.6 & 0.4 & 0.8 & 0.2 & - \\
\hline BGIZ 8 & c. $1530-1550 ?$ & 91.8 & 2.1 & 2.1 & 0.8 & 1.6 & 0.5 & 0.4 & 0.1 & - \\
\hline BGIZ 9 & c. 1550 & 87.1 & 1.5 & 1.8 & 3.1 & 1.9 & 0.6 & 0.8 & 0.6 & - \\
\hline BGIZ 10 & c. $1550-1575$ & 89.8 & 3.1 & 1.9 & 1.3 & 1.5 & 0.4 & 0.4 & 0.4 & 0.4 \\
\hline BGIZ 11 & c. 1550 & 90.6 & 2.0 & 2.5 & 1.4 & 1.8 & 0.6 & 0.6 & 0.1 & - \\
\hline BGIZ 12 & c.1530-1550 & 91.3 & 1.6 & 2.1 & 1.4 & 1.7 & 0.5 & 0.6 & 0.4 & - \\
\hline BGIZ 13 & $c .1530-1550$ & 92.6 & 1.4 & 1.7 & 1.1 & 1.5 & 0.6 & 0.5 & 0.1 & - \\
\hline
\end{tabular}

Table 2. SEM-EDS bulk analyses of slips. All results are normalized to $100 \mathrm{wt} \%$. 


\begin{tabular}{|c|c|c|c|c|c|c|c|c|c|c|c|c|c|}
\hline Code & $\begin{array}{l}\text { Production } \\
\text { date }\end{array}$ & Colors & $\mathrm{SiO}_{2}$ & $\mathrm{PbO}$ & $\mathrm{Na}_{2} \mathrm{O}$ & $\mathrm{SnO}_{2}$ & $\mathrm{CaO}$ & $\mathrm{Al}_{2} \mathrm{O}_{3}$ & $\mathrm{~K}_{2} \mathrm{O}$ & $\mathrm{FeO}$ & $\mathrm{CuO}$ & $\mathrm{MgO}$ & $\mathrm{CoO}$ \\
\hline BGIZ 1 & $\begin{array}{l}\text { c. } 1550- \\
1575\end{array}$ & turquoise & 49.3 & 35.7 & 8.1 & 4.1 & 0.8 & 0.4 & 0.9 & 0.4 & 0.1 & 0.2 & - \\
\hline BGIZ 2 & $\begin{array}{l}\text { c. } 1535- \\
1545\end{array}$ & $\begin{array}{l}\text { cobalt } \\
\text { blue }\end{array}$ & 46.6 & 29.7 & 8.7 & 5.6 & 0.8 & 0.4 & 0.8 & 0.3 & - & - & 0.3 \\
\hline BGIZ 4 & $\begin{array}{l}\text { c. } 1550- \\
1575\end{array}$ & purple & 48.1 & 35.8 & 9.3 & 3.5 & 1.2 & 0.5 & 0.9 & 0.3 & 0.1 & 0.2 & - \\
\hline BGIZ 5 & $\begin{array}{l}c .1530- \\
1550 ?\end{array}$ & $\begin{array}{l}\text { cobalt } \\
\text { blue }\end{array}$ & 48.1 & 33.1 & 10.5 & 6.3 & 0.4 & 0.2 & 1.0 & 0.2 & & 0.1 & - \\
\hline BGIZ 6 & $\begin{array}{l}\text { c. } 1575- \\
1580\end{array}$ & red & 53.7 & 28.8 & 10.4 & 3.5 & 1.5 & 0.5 & 1.1 & 0.4 & 0.2 & 0.3 & - \\
\hline BGIZ 6 & $\begin{array}{l}c .1575- \\
1580\end{array}$ & turquoise & 51.7 & 30.1 & 10.2 & 2.9 & 1.3 & 0.4 & 1.0 & 0.4 & 1.4 & 0.3 & - \\
\hline BGIZ 7 & c. 1600 & green & 48.0 & 34.7 & 8.6 & 2.2 & 0.9 & 0.5 & 0.8 & 0.3 & 1.1 & 0.2 & \\
\hline BGIZ 8 & $\begin{array}{l}\text { c. } 1530- \\
1550 ?\end{array}$ & $\begin{array}{l}\text { cobalt } \\
\text { blue }\end{array}$ & 49.3 & 32.0 & 10.6 & 5.6 & 0.7 & 0.3 & 1.0 & 0.3 & - & 0.1 & \\
\hline BGIZ 9 & c. 1550 & $\begin{array}{l}\text { cobalt } \\
\text { blue }\end{array}$ & 47.5 & 35.0 & 9.3 & 5.9 & 0.7 & 0.2 & 1.0 & 0.3 & - & 0.0 & 0.1 \\
\hline BGIZ 10 & $\begin{array}{l}\text { c. } 1550- \\
1575\end{array}$ & green & 45.9 & 40.2 & 8.7 & 3.3 & 0.4 & 0.3 & 0.8 & 0.3 & 0.3 & 0.0 & \\
\hline BGIZ 11 & c. 1550 & $\begin{array}{l}\text { cobalt } \\
\text { blue }\end{array}$ & 46.6 & 32.8 & 11.4 & 6.0 & 0.9 & 0.3 & 1.0 & 0.3 & - & 0.1 & 0.3 \\
\hline BGIZ 12 & $\begin{array}{l}\text { c.1530- } \\
1550 \\
\end{array}$ & $\begin{array}{l}\text { cobalt } \\
\text { blue }\end{array}$ & 53.5 & 29.5 & 10.9 & 3.5 & 0.9 & 0.3 & 1.0 & 0.2 & - & 0.1 & \\
\hline BGIZ 13 & $\begin{array}{l}c .1530- \\
1550\end{array}$ & $\begin{array}{l}\text { cobalt } \\
\text { blue }\end{array}$ & 51.2 & 32.5 & 8.6 & 5.5 & 0.5 & 0.0 & 1.2 & 0.1 & - & - & 0.2 \\
\hline
\end{tabular}

Table 3. SEM-EDS bulk analyses of glazes. All results are normalized to $100 \mathrm{wt} \%$. 


\begin{tabular}{|l|l|l|}
\hline & Production date & Deposition date \\
\hline BGIZ 1 & c. $1550-1575$ & c. $1600-1650$ \\
\hline BGIZ 2 & c. $1535-1545$ & c. $1600-1650$ \\
\hline BGIZ 4 & c. $1550-1575$ & c. $1600-1650$ \\
\hline BGIZ 5 & c. $1530-1550 ?$ & c. $1600-1650$ \\
\hline BGIZ 6 & c. $1575-1580$ & c. $1600-1650$ \\
\hline BGIZ 7 & c. 1600 & c. $1600-1650$ \\
\hline BGIZ 8 & c. $1530-1550 ?$ & c. $1521-1600$ \\
\hline BGIZ 9 & c. 1550 & c. $1521-1600$ \\
\hline BGIZ 10 & c. $1550-1575$ & c. $1521-1600$ \\
\hline BGIZ 11 & c. 1550 & c. $1521-1600$ \\
\hline BGIZ 12 & c. $1530-1550$ & c. $1521-1600$ \\
\hline BGIZ 13 & c. $1530-1550$ & c. $1521-1600$ \\
\hline
\end{tabular}

Table 4. The relationship between dates of production and deposition of Iznik pottery from Belgrade 


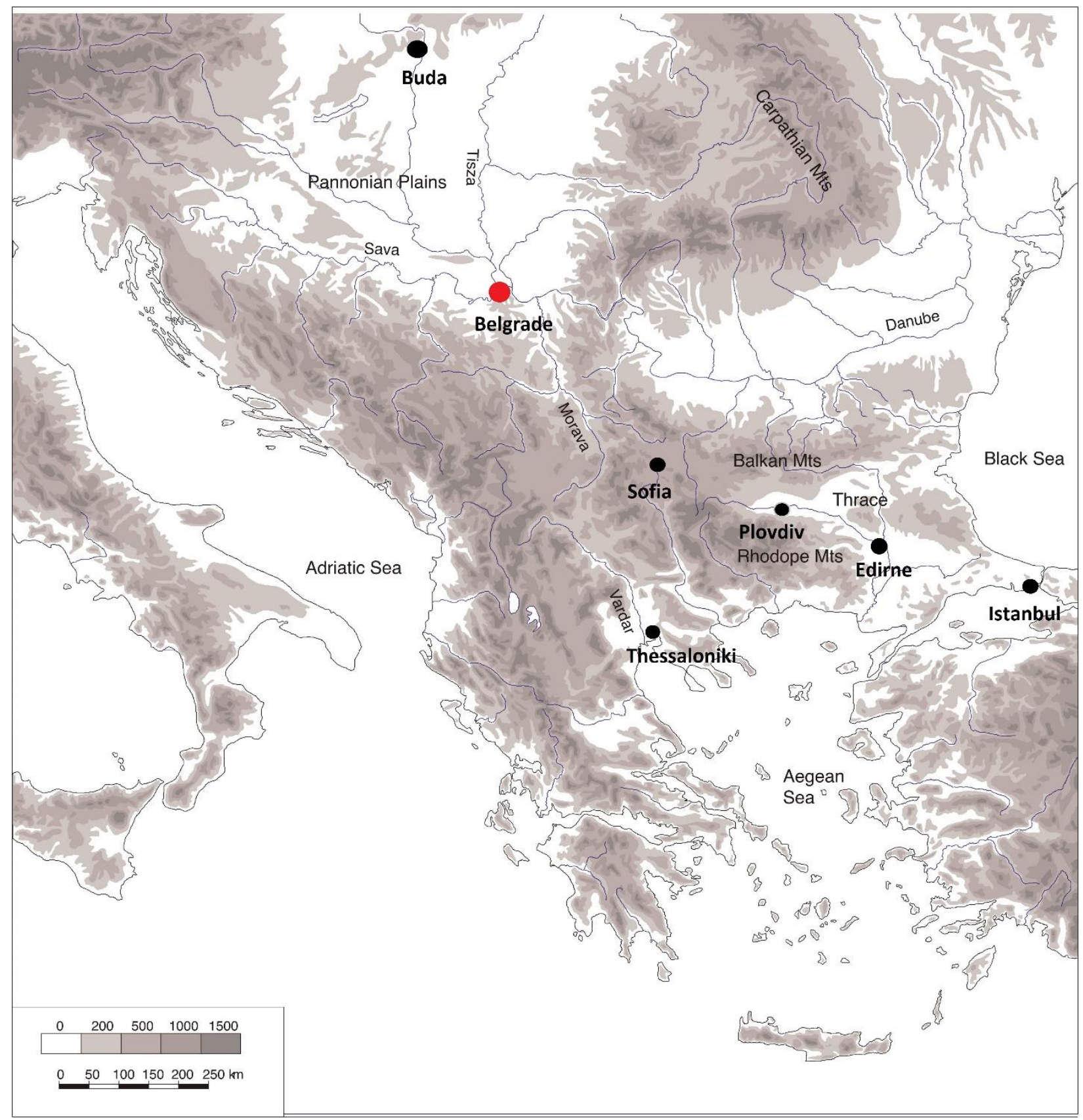

FIG. 1

Map of the Ottoman major urban centers, with the position of Belgrade 

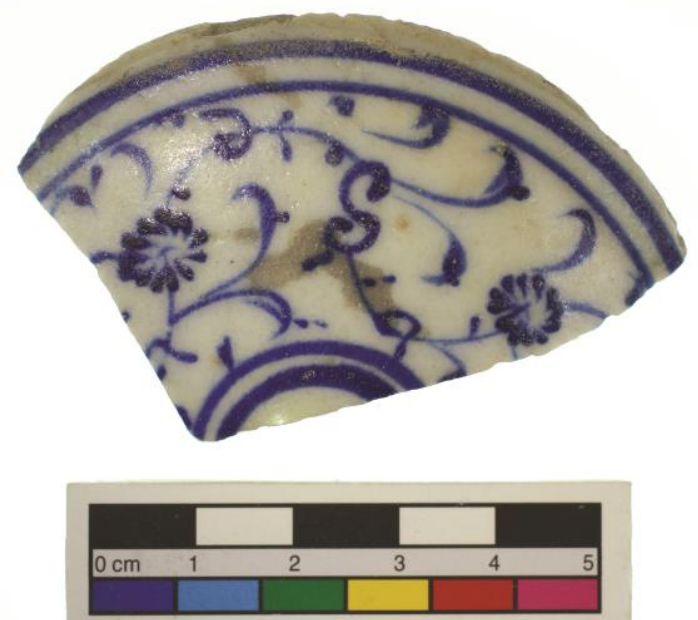

FIG. 2

Sample BGIZ 2 from the fortified suburb of the Belgrade Fortress (photo Jelena Živković)
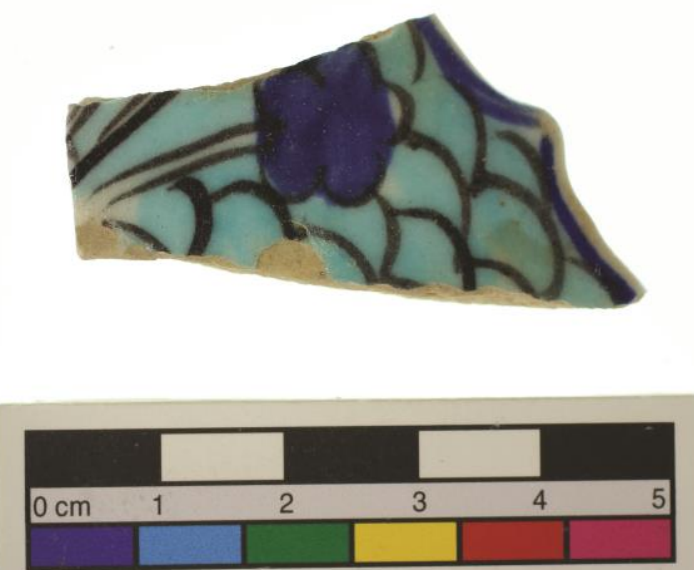

FIG. 3

Sample BGIZ 2 from the fortified suburb of the Belgrade Fortress (photo Jelena Živković) 

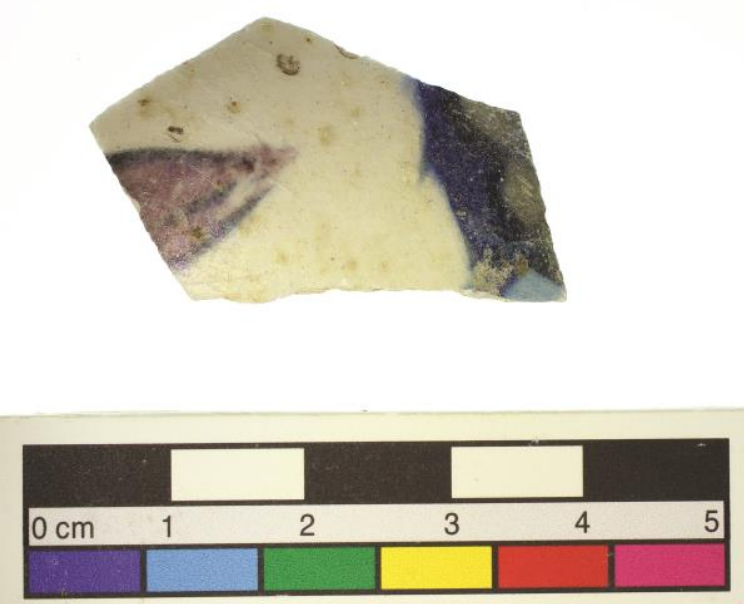

FIG. 4

Sample BGIZ 4 from the fortified suburb of the Belgrade Fortress (photo Jelena Živković)
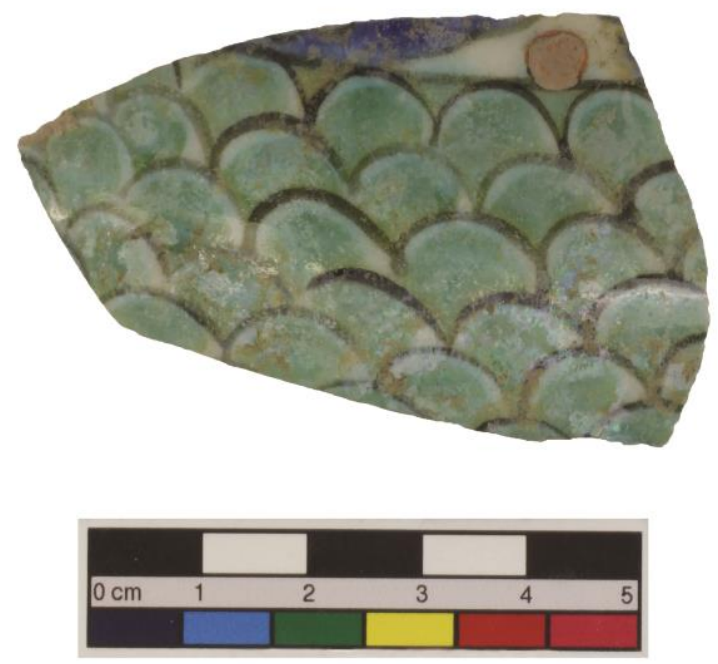

FIG. 5

Sample BGIZ 10 from huts of Lower Town of the Belgrade Fortress (photo Jelena Živković) 

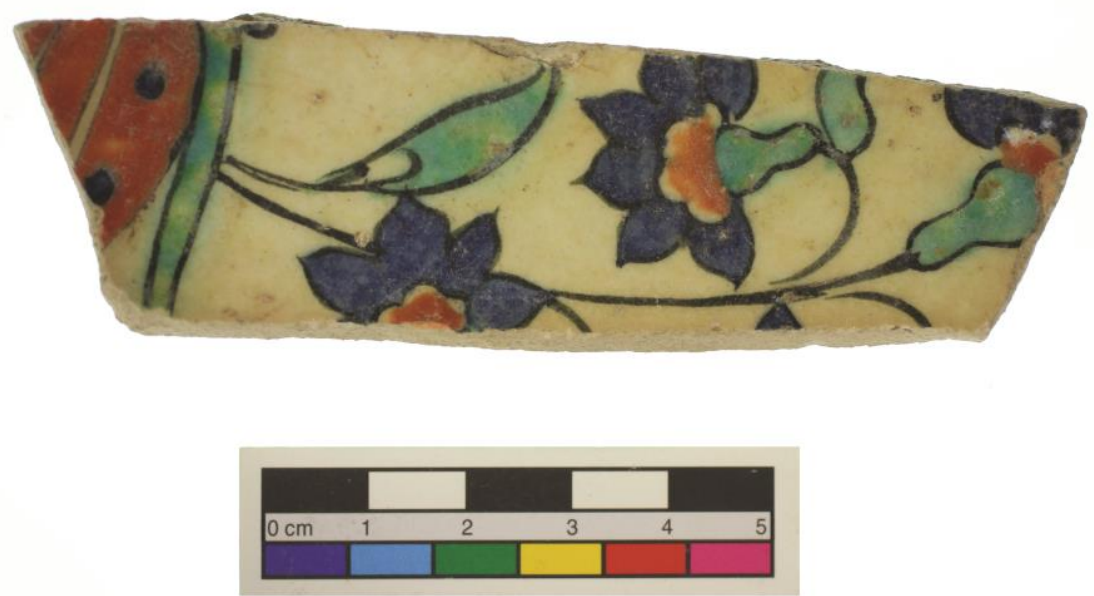

FIG. 6

Sample BGIZ 6 from the western part of Upper Town of the Belgrade Fortress (photo Jelena Živković)
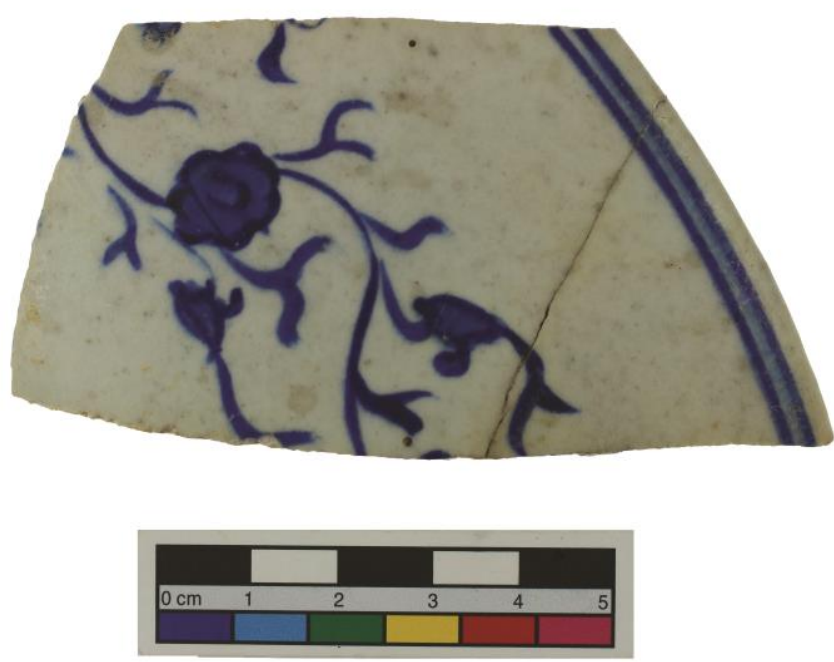

FIG. 7

Sample BGIZ 12 from huts of Lower Town of the Belgrade Fortress (photo Jelena Živković) 

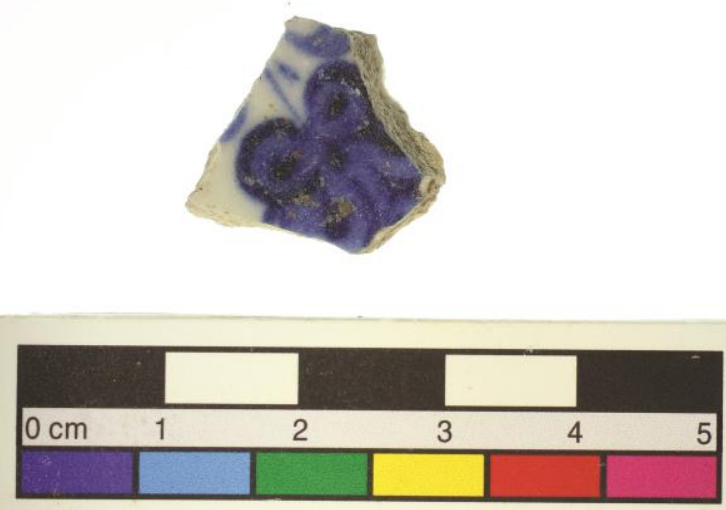

FIG. 8

Sample BGIZ 8 from the waste pit of Upper Town of the Belgrade Fortress (photo Jelena Živković)
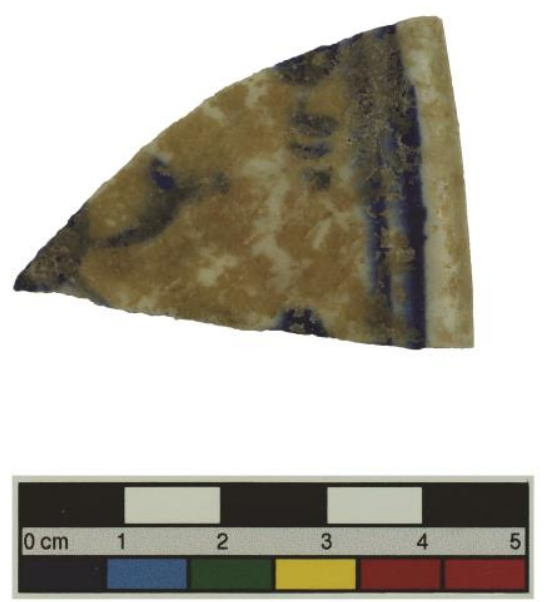

FIG. 9

Sample BGIZ 9 from the waste pit of Lower Town of the Belgrade Fortress (photo Jelena Živković) 

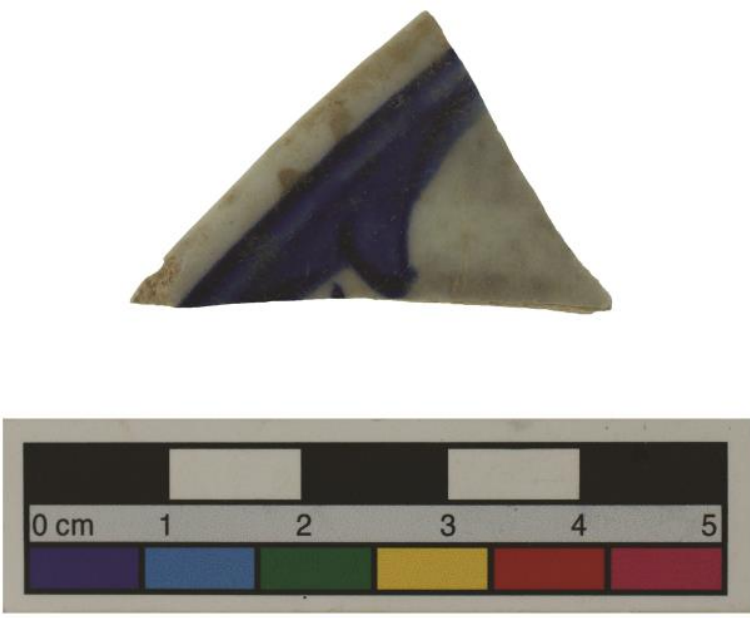

FIG. 10

Sample BGIZ 11 from huts of Lower Town of the Belgrade Fortress (photo Jelena Živković)
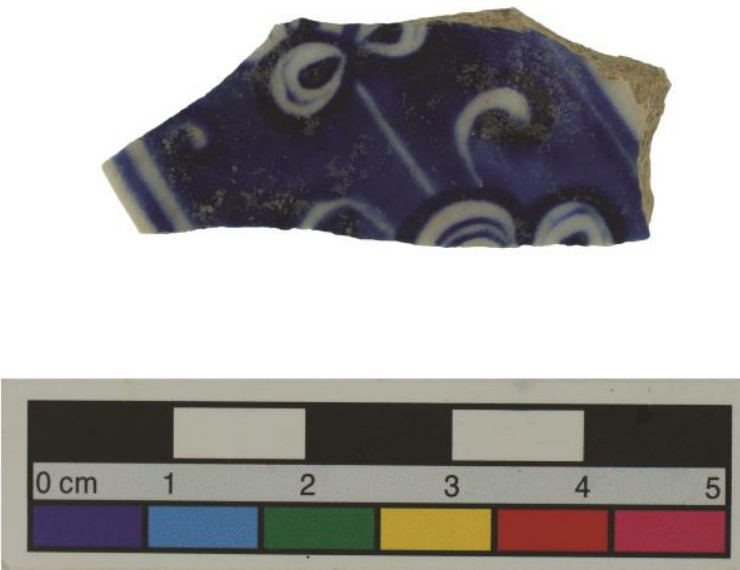

FIG. 11

Sample BGIZ 13 from huts of Lower Town of the Belgrade Fortress (photo Jelena Živković) 

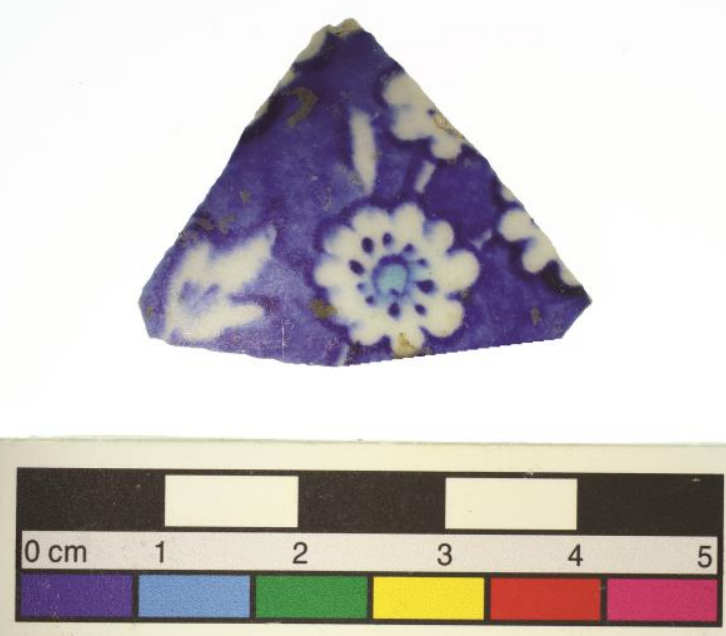

FIG.12

Sample BGIZ 5 from the western part of the Upper town of the Belgrade Fortress (photo Jelena Živković)
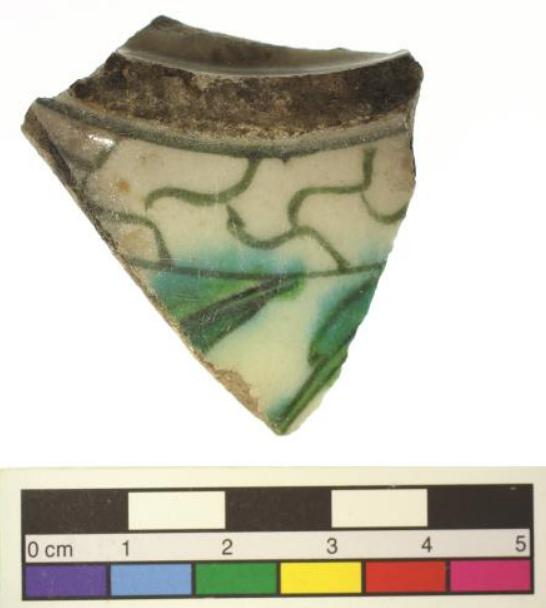

FIG. 13

Sample BGIZ 7 from the western part of Upper Town of the Belgrade Fortress (photo Jelena Živković) 
The site archive including the finds has been deposited at Institute of Archaeology, at the department for Belgrade Fortress

UCL Qatar, Georgetown Building 2nd floor, Hamad bin Khalifa University, Doha Qatar (JŽ and $M G)$

Institute of Archaeology, Kneza Mihaila 35/IV, Belgrade, Serbia (VB)

\section{NOTES}

${ }^{1}$ Key publications concerning consumption in Ottoman archaeology: Carroll 1999; Carroll 2002; Petersen 2013; Quataert 2000; Vroom 2007; Walker 2009.

${ }^{2}$ Popović \& Bikić 2004; Guštin et al. 2008; Ostapchuk \& Bilyayeva 2009.

${ }^{3}$ Baram and Carroll eds. 1999; Walker 2013.

${ }^{4}$ Quataert 2000, 9-10.

${ }^{5}$ Atasoy \& Raby 1989.

${ }^{6}$ Atasoy and Raby 1989; Carswell 1998; Lane 1957.

${ }^{7}$ Henderson and Raby 1989, 129.

${ }^{8}$ Henderson 1989; Henderson and Raby 1989; Paynter et al. 2004; Tite 1989; Tite et al. 2016.

9 e.g. Carroll 1999; Vroom 2009; Walker 2009. 
10 e.g. Kovács 2005; Holl 2005; Balla 2005; Gerelyes 2008.

${ }^{11}$ Paynter et al. 2004; Henderson 1989; Tite 1989.

12 Šabanović 1964; 1970.

13 Šabanović 1970, 938; Tričković 1992, 99-107.

${ }^{14}$ Popović 2006, 165-181.

${ }^{15}$ Popović 2006, 251-262.

16 Šabanović 1970, 13-14.

17 Šabanović 1970, 13; Evliyâ Çelebi Seyahatnâmesi, 193.

18 Popović 2006, 277-285.

${ }^{19}$ Popović 2006, 165-203.

${ }^{20}$ Popović and Bikić 2004, 109-130.

${ }^{21}$ Popović and Bikić 2004; Bikić 2007.

${ }^{22}$ Bikić 2007, Figs. 2-5.

${ }^{23}$ Bikić 2003. 
${ }^{24}$ Popović 2006, 222-224.

${ }^{25}$ Bikić 2003.

${ }^{26}$ Atasoy and Raby 1989; Carswell 1998.

${ }^{27}$ Atasoy \& Raby 1989, Bajalović - Hadži-Pešić 1984; Carswell 1998; Kovács 2005; Milošević \& Topić 2010.

${ }^{28}$ Atasoy 1989, 43-45.

${ }^{29}$ Bikić 2003, 165.

${ }^{30}$ Henderson 1989, 65-70; Paynter et al. 2004; Tite 1989.

${ }^{31}$ Brill 1999, 542.

32 Tite 1989; Paynter et al. 2004.

${ }^{33}$ Tite 1989, 124.

${ }^{34}$ Bikić 2003, 2007.

${ }^{35}$ Kovács 2005.

${ }^{36}$ Ayers 1984, 102. 
${ }^{37}$ Carroll 1999.

${ }^{38}$ Čubrilović 1974, 360; Inalcik 1994, 256-271.

${ }^{39}$ Veselinović 1984.

${ }^{40}$ Bajalović - Hadži Pešić 1984, 321-323; Bikić 2006, 209-210.

${ }^{41}$ Carroll 2002, 173.

${ }^{42}$ Kovács 2005.

${ }^{43}$ Radić 2015.

${ }^{44}$ Milošević \& Topić 2010.

${ }^{45}$ Bikić 2012.

${ }^{46}$ Carroll 2002, 172-173; Gerelyes 2005.

${ }^{47}$ Henderson 1989; Henderson and Raby 1989; Paynter et al. 2004; Tite 1989; Tite et al. 2015.

${ }^{48}$ Raby 1989, 63-64.

${ }^{49}$ Carroll 1999, 184-186. Atasoy \& Raby 1989, 273-285 